\title{
Mannheim-Heidelberg 2000
}

\author{
By Ron Holloway
}

Spring 2001 Issue of KINEMA

\section{9th INTERNATIONALES FILMFESTIVAL MANNHEIM-HEIDELBERG}

To my knowledge, an oddity like this has never happened before -- even Michael Kötz, director of the 49th Mannheim-Heidelberg International Film Festival (9-18 November 2000), thought it "one for the books." For not only did the Ecumenical Jury and the FIPRESCI (International Critics) Jury bestow their awards on David Ondíek's Samotárí (Loners, Czech Republic), but they also cited the same short film, David Lansmann's Les Chaussettes sales (Dirty Socks, France), for a special mention.

Obviously, the juries shared a mutual fascination for the narrative style and visual structure, honed to perfection, in Loners. Herewith the Ecumenical Jury's citation: "With convincing acting portraits the director sketches a tragicomedy imbued with absurd humour of the life-style of young people in Prague that focuses on the loss of value and perspectives balanced by the search for new orientation." The FIPRESCI Jury praised the filmmakers "for putting together the pieces of the particular lives of young urban people into an unconventional structure."

In other words, director David Ondíek (he's the son of veteran Czech cameraman Miroslav Ondíek), together with screenwriter Petr Zelenka (his parents are both acknowledged script-writing talents), have accurately taken the pulse of Prague's younger generation in this amusing tangle of interlocking moral tales. No wonder it's the commercial hit of the season -- and no wonder New Czech Cinema directors command 25\% of their home box office!

As for Dirty Socks, this laconic French fable chronicles the plight of a Good Samaritan who befriends an unwashed ex-jailbird by offering him the possibility of a shower in his apartment, along with a clean pair of socks, only to find himself thereafter besieged for more assistance by the new-found "pal." The Ecumenical Jury singled out the film "for its reflective manner of depicting a situation all of us have been confronted with."

In retrospect, this year's Mannheim-Heidelberg festival was noteworthy for its broad range of remarkable moral tales woven from diverse national cultures. In Nabil Ayouch's poetic fiction-documentary Ali Zaoua (Morocco-France), given the prestigious Art of Film Award of the International Jury -- by the way, it received the Ecumenical Prize at the Montreal World Film Festival last September -- the focus is on street children in Casablanca confronted with the dilemma of hiding the corpse of one of their own until he can be buried at sea in the sailor-suit he had requested. In Alain de Halleux's Pleure pas, Germaine (Don't Cry, Germaine, Belgium), a poignant tragicomedy voted the Audience Award, a worn-out wife and mother wrestles with the illusions of the oldest child in her brood -- her husband -- during a trip across France to "return home" to her native Basque country.

Another festival highlight was Milutin Petrović's Land of Truth, Love and Freedom (Yugoslavia), awarded the Rainer Werner Fassbinder Prize. Shot with a hidden video camera under the very noses of Slobodan Milošević's heavily armed police, the cassettes were then spirited off to a Budapest laboratory for a $35 \mathrm{~mm}$ transfer. By the time Petrović premiered the zero-print of his black comedy on the local mafia scene at the Mannheim-Heidelberg festival, Belgrade had a new government -- and the new cultural ministry under Vojislav Kostunica rewarded his efforts with extra prints for festival circulation.

In Arto Paragamian's Two Thousand and None (Canada), another audience favourite, John Turturro plays a university paleontologist who suddenly discovers he is afflicted by a rare brain disease and has but a few weeks more to live -- enough time to right a few wrongs of the past and to fill these days with moments of playful absurdity. Similarly, in Monkey Business (Finland), a group of old chums meet again, now as middle-aged lotharios, to resurrect their garage-rock-band and perform at a friend's wedding -- only to be confronted by some truths about their dreams, their destinies, themselves.

Two Iranian films -- Rafi Pitts's Sanam in the Competition, Maryam Shahriar's Daughters of the Sun in the Discoveries -- depict the harsh conditions facing women before, and after, the Revolution. In Sanam the 
woman in the title adamantly protests the charge that her murdered husband was a horse-thief -- all to no avail, for the steppes in northeastern Iran are far from civilization, and only the voices of the mighty are heard. Social conditions appear even worse in Daughters of the Sun, in which impoverished parents cut the hair of their young daughter, disguise her as a boy, and send her off to work at a carpet-weaving compound. Tragedy is preordained.

Two Special Screenings were festival draws. Wilfried Huismann's Lieber Fidel (Dear Fidel, Germany) proved an engrossing polit-documentary on several counts. The story of Marita Lorenz, the daughter of German ship captain who had an affair with Fidel Castro, was also the lover of Venezuelan dictator Marcos Perez Jimenez, and worked for a time as an underground CIA agent, her life-story strains the limits of beliefs. And though some of her recollections (as penned in a recently published biography) can be questioned, still it's hard to ignore that voluminous collection of letters, photos, factual records, and related memorabilia that back up her claims. Besides, before the camera, Marita can weave some bewitching tales of political intrigue.

The turnout for Dito Tsintsadze's Lost Killers, the other Special Screening, hardly needs explaining -- the Georgian director shot the film in Mannheim. A spoof of the mafia-hitman genre, spiced with light Georgian wit and black Balkan humour, as personified by the "lost killers," the film is less a story than a string of improvised anecdotes -- some funny, some cryptic, all highly amusing.

Filmmakers confirmed on several occasions that they enjoy the warm, easy-going atmosphere of this "twincity" festival. Sarah Shute came all the way from Los Angeles to present Lunch (USA), a 3-minute, American Gothic vignette about retirement on a park-bench in the middle of nowhere. Patrick Demers's Décharge (Discharged, Canada) effectively demonstrates how a DV-camera project, shot during a weekend in the country, can be fashioned during post-production into a tight 13-minute psycho-drama with striking blackand-white images. And attracted by the possibility of ten screenings on the festival schedule, Berlin producer Regina Ziegler opted for Mannheim-Heidelberg to premiere Amos Kollek's Angela (USA-Germany), a sidesplitting, mistaken-identity, senior-citizen Erotic Tale shot against the backdrop of Manhattan's Central Park.

\section{References}

\section{AWARDS}

Art of Film Awards of Mannheim-Heidelberg

Best Feature Film: Ali Zaoua (Morocco-France), Nabil Ayouch

Best Documentary: Pardevant Notaire (A Country Solicitor, France), Sophie Bruneau-Roudil, MarcAntoine Roudil

Best Short Film: Hver søndag hos more (Sunday Dinners at Mom's, Norway), Jens Lien

Rainer Werner Fassbinder Prize: Zemlja istine, slobode i ljubavi (Land of Truth, Love and Freedom, Yugoslavia), Milutin Petrović

Special Jury Award: Sanam (Iran), Rafi Pitts

\section{Special Mentions}

Samotári (Loners, Czech Republic), David Ondíek

Apinajuttu (Monkey Business, Finland), Esa Illi

\section{Audience Award}

Pleure pas, Germaine (Don't Cry, Germaine, Belgium), Alain de Halleux

\section{FIPRESCI (International Critics) Award}

Feature film: Samotárí (Loners, Czech Republic), David Ondíek

Short film: Les Chaussettes Sales (Dirty Socks, France), David Lanzmann

Ecumenical Jury

Feature film: Samotárí (Loners, Czech Republic), David Ondíek 
Special mention: Les Chaussettes Sales (Dirty Socks, France), David Lanzmann

Jury of Cinema Owners

Sanam (Iran), Rafi Pitts

Ali Zaoua (Morocco-France), Nabil Ayouch

Two Thousand and None (Canada), Arto Paragamian

Samotáři (Loners, Czech Republic), David Ondíek

\section{Author Information}

Ron HOLLOWAY (1933-2009) was an American critic, film historian, filmmaker and correspondent who adopted Europe as his home in the early fifties and spent much of his life in Berlin. He was an expert on the study of German cinema and against all odds produced, with his wife Dorothea, the journal German Film, keeping us up-to-date with the work of directors, producers and writers and the showing of German films around the world.

In 2007, Ron Holloway and his wife were awarded the Berlinale Camera Award. Ron also received the Bundesverdienstkreuz (German Cross of Merit), Polish Rings, Cannes Gold Medaille, the American Cinema Foundation Award, the Diploma for Support of Russian Cinema and an honorary award from the German Film Critics' Association.

Ron was also a valued contributor to Kinema for the past fifteen years. 